\title{
Hurston's "Real Negro Theatre": Participation Observation of African American Folk
}

\begin{abstract}
This article explores Zora Neale Hurston's theatrical project "real Negro theatre." If regarded from the standpoint of current ethnomethodology which emphasizes dialogue and interaction between ethnographer and their informants, Hurston's realization of the theatre in the South can be classified from the ethnographic point of view as ahead of its time. The main argument of this article is that Hurston turned around the technique of participation observation for the purpose of the theatre and envisaged active engagement of an audience which was familiar with the presented forms. Moreover, due to the fact that her performance was supposed to function as a display of folklore in the process of creation, the practical realization of the theatre was a development of African American folk aesthetic in the institution of a theatre and an original contribution to the New Negro discourse. Analyses of The Fiery Chariot (1932) and Spunk (1935), two plays closely affiliated with this project, are included.
\end{abstract}

\section{Key words}

Zora Neale Hurston; "real Negro theatre"; The Fiery Chariot; Spunk; participation observation

Due to her anthropological training under Franz Boas in the late 1920's which significantly influenced Hurston's literary maturity Zora Neale Hurston represents a complicated figure in the New Negro movement. Despite her sensitive blending of fiction with ethnographic findings, scholarly insights into her fictional works often lack the interdisciplinary dimension that they deserve. Moreover, the innovative ethnomethodology behind Hurston's plays from the 1930's which were written shortly after her research in the South is often overlooked as a result of the 
distance between Hurston's current and intended audiences. It is in particular her version of a folk play in the first half of the 1930's, concocted from her fieldnotes with the intention to be performed for the African American audiences, that provides the motivation for analysis in this paper. Established on W.W.B. Du Bois's idea of a "real Negro theatre" (Cole and Mitchell 2008: xvii) and Alain Locke's drama of racial expression, Hurston's "real Negro theatre" (Kaplan 2002: 259) can be analyzed in relation to Hurston's ethnographic work. Believing in the relevance of her research for the national scene of African American art and culture, Hurston employed the idea of cultural relativism to contribute with her fiction to the New Negro discourse. Her plays, set in the enclosed milieu of an all-black town, a lumber camp, and the jook, provide a form of audiovisual access to the oral culture of her informants.

Starting with the performance of her research in The Great Day for a New York audience in 1932, Hurston recycled this performance for audiences throughout the South in her later plays called From Sun to Sun (1932) and All De Live Long Day (1933). Hurston's 1932 plan to build a theatre in the rural South, where audiences had a greater potential to recognize and identify with her performance, reveals a new departure from Du Bois's conception of African American theatre and can be also viewed as a deliberate work on her part to turn around the ethnographic technique of participant observation for theatre with the intention of validating and perpetuating the characteristics of African American expression. Despite the fact that the analysis of traditional participant observation, which masks the encounter between the ethnographer and their informants, proves problematic in Hurston's fiction, its modern equivalent, with its emphasis on dialogue and interaction between the subject and the ethnographer, enables a study of Hurston's collections of folklore, novels, and also plays from the ethnographic point of view. Hurston was a trained ethnographer and an innovative writer who kept challenging the schism between the objective and subjective realms of cultural experience. My argument is that Hurston's conception of the "real Negro theatre" was based on the same principle as participation observation. The actualized performances in the rural South where her research had taken place were supposed to stir the "creative urge" (Kaplan 2002: 277) of the community. Just as Hurston, the observant ethnographer, became a participant in the culture under research, so the audience, observing the performance in the institution of a theatre was expected to participate in Hurston's performances. In this paper, I focus on the analysis of The Fiery Chariot (1932) and Spunk (1935) both closely associated with Hurston's project.

One of the challenges the African American intellectual elite in the early twentieth century faced was the establishment of an African American theatre that would improve the image of the African American community as well as nurture future generations of New Negroes. In 1926, Du Bois, while maintaining that the African American theatre groups missed "the real path" articulated his influential definition of "race drama" (Krasner 2002: 214). The "real Negro theatre" (Krasner 2002: 229) was to be: 
1. About us. That is they must have plots which reveal real Negro life as it is. 2. By us. That is, they must be written by Negro authors who understand from birth and continual association just what it means to be a Negro today. 3. For us. That is, the theatre must cater primarily to Negro audiences and be supported and sustained by their entertainment and approval.

4. Near us. The theatre must be in a Negro neighborhood near the mass of ordinary Negro people. (Krasner 2002: 214)

In short, Du Bois's conception of the African American theatre was formulated with the idea of establishing drama that would be primarily subject to the African American community with the intention of elevating the intellectual level of the audience and future African American dramatists. The emphasis on the improvement of social, moral, and intellectual standards, which was the core of Du Bois's ideology, corresponded with the New Negro aims to refute stereotypical images of African Americans in the eyes of Anglo-American public. The need to create a "refined" African American audience came from the uneasiness the New Negroes leaders felt when observing the behavior of African Americans in a theatre. "Du Bois, along with many members of the intellectual elite, objected that black audiences brought the same jocund and participatory behavior to serious theater as they did to variety acts, laughing at the wrong moments and talking to the performers" (Cole and Mitchell 2008: xvii). Du Bois, therefore, desired theatre that was based on "realism" with the purpose of giving rise to "serious theatre" (Cole and Mitchell 2008: xvii) that would engage the masses in conversation about African American social consciousness. His practical realization of the "About us, By us, For us, Near us" theatre was, in effect, a popular means to promote socio-political cause.

Even though Hurston was among playwrights who were guided by Du Bois's influential conception of African American theatre (Wintz and Finkelman 2004: 77), her appreciation of the distinct features in African American culture led her to redefine Du Bois's four rules for the theatre. While Du Bois wished to cultivate his audience as well as expand its socio-political awareness, Hurston's plan for "the new, the real Negro art theatre" (Kaplan 2002: 116), was to work closely with the characteristic features of African American folk art and to engage the folk community in the development of its forms. In "The Observation of Participation and the Emergence of Public Ethnography," an article from 2005 which deals with recent developments in ethnography, Barbara Tedlock discusses the potential of theatre for ethnographic research. Her ideas serve as a backbone for my analysis of Hurston's own version of African American theatre due to its emphasis on the active role of spectators in the creative process:

Because culture is emergent in human interaction rather than located deep inside individual brains or hearts, or loosely attached to external material objects or impersonal social structures, dramas are a powerful way to both shape and show cultural construction in action.... Actors communicate, by means of gesture and other bodily forms, an understandable and believable 
mimetic reality for their spectators. Such performances operate on a feedback principle of approximating reality by checking the details and then refining the representation in a reiterative or "closed loop" approach.... Because of these and other characteristics, popular theatre, with its egalitarian "by the people, for the people" ethos, serves as an imitation of aspects of the sensible world, and thus is a form of cultural mimesis or representation. (Tedlock 2005: 155)

In this extract, Tedlock discusses theatre as a possible tool for modern ethnography which, as opposed to traditional ethnography, focuses on the cross-cultural experience itself and not the study of the culture of the other $(2005: 151)$. Theatre, which has the ability to bridge the cultural gaps in the form of theatrical experience, has been recognized by ethnographers as useful because it provides mimesis of cultural performances in which individuals engage every day (2005: 152). Due to the direct interaction of audience with the performance, the theatrical event can function as a cultural "dialogue" between the ethnographer and community, within the community, and across communities, and has therefore a considerable potential for political action. Hurston's vision for the African American theatre in 1932, that was supposed to be established in the rural South and recreate folkloric and cultural events by local actors, suggests Hurston's preference for cultural production from within and by the community. The elevation of the daily performances of the community in a theatre was a way to further develop their "profound expressions of group behavior" (Hemenway 1977: 168) and, given the connection between African American folklore in the rural South and national African American art which Hurston perceived, empower African American community. In the local context, performances based on intrinsic features of cultural expression were supposed to result in cultural events of their own.

Hurston's first attempt in performing the ethnographic data she had collected and later published in Mules and Men (1935) was The Great Day (1932), first presented in the Golden Theatre in NYC on Jan 10, 1932. Starting out as an idea of "a Negro concert of the most intensely black type" (Kaplan 2002: 228), the potential of Hurston's collections to be realized on stage inspired the author to create a social performance that centered around music and dance. According to Hurston, music was "an integral part of all folkloric events" (Hemenway 1977: 177). Moreover, Hurston's comment on the role of music in the lives of the African American community reveals her interest in participation of the audience in her performance: "My people are not going to do but so much of anything before they sing something" (Hemenway 1977: 177). The resulting product was The Great Day, a play which was "loosely structured around a single day in the life of a railroad work camp" (Hemenway 1977: 178).

As indicated, The Great Day became Hurston's main occupation for several years and it was after her departure for Florida that the idea of "the real Negro theatre" fully developed. Beginning as a suggestion to Langston Hughes during her research in 1928 (Kaplan 2002: 116), after the "artisitic [but not financial] success" (Hemenway 1977: 181) of The Great Day in 1932, Hurston realized that 
"the real Negro theatre is yet to be born" (Kaplan 2002: 259) and, when she settled in Eatonville, she contacted Rollins College in Winter Park whether it would be interested in providing roof for her new theatrical project. In an introductory letter to Edwin Osgood Grover, Hurston described her performance and success in New York as well as her future plans:

Now the material used in these concerts was gathered for the most part in Orange County. All of it came from Florida and so I thought that it would be fine to give series, or one at least in the native habitat of the songs and tales. And I wondered if Rollins College would be interested thru its Dept. Of Anthropo., its Music dept., and since I am setting down the tales in a book, if the chair of Books would not like to assist in putting the world right on Negro expression. (Kaplan 2002: 259)

In this letter, Hurston acknowledges her long-going project for recognition of African American culture and her interest in developing her African American theatre project. Given the fact that Hurston knew the presented folklore must have been familiar to the African American audiences in Florida at least to some extent, its appropriation in the theatrical context was supposed to encourage the audience in its development.

Hurston's plan for the theatre was based on interaction with the African American audience. In following letters to Grover, in which they further discussed details about possible collaboration between her and the Rollins College, Hurston expressed her wish to build a theatre in Eatonville, a self-governing all-black town in which Hurston grew up: "I would love more than anything else to build a playhouse for our use here. The whole town is excited about the project. You know we are a dramatic people. I mean that literally. We dramatize every waking moment of our lives" (Kaplan 2002: 260). The eventual support from Rollins resulted in basically the same performance as The Great Day but it was titled From Sun to Sun (1932). For the cast of the show, Hurston "recruited her performers largely from Eatonville friends and relatives. ... She even convinced her uncle, the reverend Isiah Hurston, to give the sermon sequence" (Hemenway 1977: 184). From Sun to Sun was first performed in January 1933 in a small experimental theater, but it was so well received that a second performance was given in February at Recreation Hall on the campus of Rollins College and additional concerts were scheduled for other Florida cities. When the performance took place in Eatonville, "it was a special source of community pride" (Hemenway 1977: 184-185). Excited about her success in the area and not considering the difficulties to establish a Negro theatre in the segregated system of the South, Hurston wrote to Mason about giving "a real creative urge a push" in the form of theatre (Kaplan 2002: 277).

The emphasis on the word "real" reveals Hurston's intention to appropriate authentic folklore for the stage so that the resultant performance stirs the audience to produce a wave of creative response. When another concert, this time titled All De Live Long Day, was scheduled in 1934, Hurston clarified the difference 
between her concerts, that aspired to present authentic African American folk music, and other concerts for which the original music was arranged: "When musicians arrange these songs they make anthems out of them. 'I've got a rainbow wrapped and tied around my shoulder' becomes 'rain, rain, rain,' and 'bow, bow, bow' as the conductor manipulates his hands, in a way that would make the original Negro singer listen as curiously as you do. But sing a song as they [the folk] sing it and everybody joins in" (Hemenway 1977: 204-205). Even though Hurston acknowledged the qualities of arranged music, her interest lay in the participation of her listeners in singing. This concept of a performance which is based on the participation of the audience in a cultural event, can be analyzed from ethnographic point of view. Hurston's work as a playwright and director who specifically designs her performance to provoke a response from the audience can be compared to the efforts of an ethnographer to stage the circumstances surrounding the subject of research in a way that delivers desired data.

Participant observation, "the classic formula for ethnographic work" (Clifford 1986: 1) and a technique that is predominantly based on the interaction of the ethnographer with their informants, is a scientific method that was well known to Hurston as one of Boas's students. In accordance with this method, ethnographers were supposed to live in the community for a period as long as 2 years, actively engage in the daily activities of its members, and observe the socio-cultural system within which they lived. During her fieldwork in the South, Hurston used this method to collect relevant data for her research. Despite the role of subjectivity in the social encounter between Hurston and her subjects, according to the methodology of participant observation aspiring to the scientific world during the time Hurston did her research, the ethnographers were supposed to eliminate the role of their own presence in their observations. This schism within participant observation, that Hurston was well aware of and managed to avoid in Mules and Men, has been criticized under the pressure of discussion concerning the objectivity of scientific discourses in 1960's. As a consequence, there has been a shift in perspective of the method and a new genre called autoethnography, or "the observation of participation" (Tedlock 2005: 151) emerged.

Following the "crisis of representation" in ethnography (Marcus and Fischer 1999: 8), the presence of the ethnographer in the interaction with the subject has been acknowledged and uncovered. The recent view of ethnography proposes that participation observation should be concerned with the interaction itself rather than attempting to represent the lives of its subjects. Moreover, the work of the ethnographer, who operates within the culture under research and is affected by it, should deal with this influence by being open to forms of expression of that culture. Interestingly enough, the same standpoint concerning the role of ethnography was held by Hurston in the mid 1930's:

The major problem in my field as I see it is, the collection of Negro folk material in as thorough a manner as possible, as soon as possible. In order for the collection to [be] exhaustive, it must be done by individuals feeling 
the materials as well as seeing it objectively. In order to feel it and appreciate the nuances one must be of the group. In order to see it objectively one must have great preparation, that is if [one is] to be able to analyze, to evaluate what is before one.

In my humble opinion, it is almost useless to collect material to lie upon the shelves of scientific societies. It should be used for the purpose to which it is best suited. The Negro material is eminently suited to drama and music. In fact it is drama and music and the world and American in particular needs what this folk material holds. (Hemenway 1977: 207)

This extract from Hurston's correspondence reveals her dissatisfaction with the methodology of ethnography during 1930's. Pointing at the inefficacy of scientific approach, Hurston argues for the use of different form, which is, in case of African American folk culture, drama.

Hurston's objections to ethnomethodology came from her experience in the field and her recognition of organic qualities of African American folklore. Initially unsuccessful with her research for Woodson and Boas in 1927, during her second trip between 1928 and 1929, which was funded by Mason, Hurston explored her own dramatic skills to penetrate the enclosed social system of her informants. She used theatrical techniques to be able to participate in the daily lives of the community. In Mules and Men, Hurston describes her method in which she pretended to be outcast of the law in order to break the "feather-bed resistance" (10) of the African American community in the Loughman lumber camps. Her technique informs the reader about the social conditions of the workplace. According to Patterson, violence and criminality was part of the workers' experience and "none of the violence was of concern to the authorities" (Patterson 2005: 136). However, though Hurston's technique is of informational value, the interest of this thesis lies in the theatrical act itself. Hurston deliberately staged her own performance in order to be able to engage in the activities of the researched community.

This method, in which the ethnographer consciously acts to create a situation that might lead to interaction with the subject and has to improvise to maintain the connection, is essential to participant observation. As can be seen in case of Hurston, the events that form the encounter between the fieldworker and their informants are staged and acted up. The fieldworker engages their own consciousness to create a "fiction" that has the power to interact with "reality" which becomes the area of ethnographic research. As Hurston became increasingly drawn into the social system of the community, she learned to understand its rules and, as a consequence, became a participant. From the midst of her research, she wrote: "I am truly dedicated to the work at hand and so I am not even writing, but living every moment with the people" (Hemenway 1977: 112). Blurring of reality and fiction constitutes interaction between the ethnographer and their subjects, as could be seen in the acceptance of Hurston by her subjects and the acceptance of her informants' vision by Hurston. The ethnographer engages in the reality of the 
subject's experience with fiction, which is determined by his position as an intruder, in order to provoke participation of the subject, who can decide to ignore the ethnographer. As Castañeda reminds the reader, the staged situation is "defined" (2006: 88) as real and the emerging event as well, the interaction of fiction and reality, forms a reality of its own that reveals the nature and quality of subject's response. The same principle of reality appears in the theory of theater which has recently focused on the role of spectatorship in a theatrical performance.

Theatre, as well as the technique of participant observation, can be analyzed as an event based on blurring of fiction and reality. According to Schechner, "theater is a middle world where groups actually interact not only through audience participation but by subtler means of audience inclusion and environmental staging. Theater combines artistic-composed behavior (what I call 'restored behavior,' see Schechner 1985) with everyday-spontaneous behavior" (Schechner 2003: 162-163). The "middle world" is the reality which is based on the interaction of the fictional realm of performance with its spectators, who, from this perspective, are regarded as active participants. By their participation, the audience can embody the performative potential of the performance. It is the idea of active, participating audience which is in power to emerge as a collective force that connects Boal's theatre of the oppressed to Hurston's "real Negro theatre" in which the African American community is put in the charge of development of African American culture.

\section{The Fiery Chariot and Spunk}

The concert performance The Great Day (1932), and its revised versions From Sun to Sun (1932) and All De Live Long Day (1933), both presented to the southern audiences, inspired Hurston's plays The Fiery Chariot (1932) and Spunk (1935). While The Fiery Chariot was actually performed in From Sun to Sun, a wide variety of Hurston's folklore originally staged for The Great Day was used in Spunk. Given the fact that these plays were affiliated with the productions that were conceived as a step towards Hurston's "real Negro theatre" in the South, they are my focus here. While The Fiery Chariot complicates the plot of a well-known folk tale in accordance with the practice of signifying, Spunk encourages the audience to sing along with the performers. The merit of the plays resides in the conscious effort of the author to appeal to an African American audience which is familiar with the presented forms of expression. The audience was encouraged in its participatory behavior with the intention to give rise to an event which would empower African American culture. My objective is to simply identify what the audience was to observe and analyze the content of the plays in relation to Hurston's ethnographic research. I will discuss the ways The Fiery Chariot and Spunk are embedded in African American folklore and surpass Hurston's findings from the field to engage the audience in the development of African American expression. 


\section{The Fiery Chariot}

The Fiery Chariot was based on a story that Hurston had collected in Polk County in the late 1920's and later published in Mules and Men (1935) as "Ole Massa and John Who Wanted to Go to Heaven." (73). Comparison between the story in Mules and Men and the play is crucial because it enables the reader to discern ways in which Hurston made changes to the original story. The original tale introduces the classic African American folk hero - High John de Conquer, High John, or simply John (Sanfield 1989: 5). The main purpose of stories about John was training in Signifying, a rhetorical practice mainly employed by the African American community. John was a well-known figure all over the South and a popular version of the African American trickster. In order to engage the audience in the performance, Hurston transformed the story in accordance with elements of African American folklore. The main difference between the original story and Hurston's performance is the shift of focus from two main characters to three, challenging the audience as to who is the real trickster along the way.

According to the formula of the plantation stories about John, the trickster, John verbally outwits his master with his deliberate disruption of the literal by the figurative. As in the case of the Signifying Monkey, who lacks the physical strength of the Lion and the Elephant, both appearing in these stories by the Monkey's side, "a trickster in the African-American tradition is one who flouts the norms of society, using cunning, humor and deceit to obtain personal gain. Often this character embodies a limitation of some sort, one who is likely to be trod by others to with more power and physical strength" (Smith 2005: 179). The figure of John, a man who has been enslaved for the rest of his life to his master, represents the trickster because he challenges his master by means which is available to him - his wit. Despite the limited options due to his status as a slave, John is able to rhetorically triumph over his master and represents the folk hero of the African American South. Indeed, in a letter to Alain Locke from the early 1940's, Hurston wrote: "High John is the real hero. ... High John de Conquer runs all through our folklore. He is really Brer Rabbit, the hero who wins by a ruse" (Kaplan 2002: 489).

Even after the Emancipation Proclamation, this folk hero was maintained in folk stories shared among the members of the African American community as a result of the racial and economic segregation of the American South. What John meant for the African Americans in the South between 1920's and 1940's is revealed by Hurston: "Hundreds of thousands, perhaps millions of Negroes in America are carrying about on their persons a bit of root known as High John de Conquer at this moment and it is their most valued possession" (Kaplan 2002: 489). What Hurston suggests by "their most valued possession" can be identified as Signifying, developed and maintained by these tales.

Signifying, a rhetorical practice which was widely spread in the African American community in the 1930's, forms the basis of my analysis of The Fiery Chari$o t$. As the folk tales about the trickster John were known to the audience, Hurston challenged the audience by complicating the structure of the story originally pre- 
occupied with the confrontation of John and Ole Massa. More importantly, she did so in accordance with the practice of Signifying. According to Gates, Jr., "the narrator's technique, his or her craft, is to be gauged by the creative (re)placement of these expected or anticipated formulaic phrases and formulaic events, rendered anew in unexpected ways. Precisely because the concepts represented in the poem are shared, repeated, and familiar to the poet's audience, meaning is devalued while the signifier is valorized" (1988: 61). Hurston, in The Fiery Chariot, preserved most of the original story in her script but she reshuffled the key parts in a way that changes meaning of the original story. The original duo of the tricksters shifts to trio in accord with the Signifying Monkey tale.

If read as a Signifying Monkey tale, Hurston's The Fiery Chariot is a demanding play which requires attention from its audience because the original plot of the folk story "Ole Massa and John Who Wanted to Go to Heaven," in which the main focus is on the conflict between John and Ole Massa, is extended to the conflict between Ike and his wife Dinah, who are both renamed in the play from John and Liza. Even though it is tempting to read the play as the folk tale, as a clash between the oppressive master and the trickster, failing to take into account Dinah's presence and voice is a simplification of the complex confrontation taking place in the play. Similarly, "while other scholars have interpreted the Monkey tales against the binary opposition between black and white in American society, to do so is to ignore the trinary forces of the Monkey, the Lion, and the Elephant. ... to reduce such complex structures of meaning to a simple two-term opposition (white versus black) is to fail to account for the strength of the elephant" (Gates, Jr. 1988: 55). Due to the fact that Hurston had to challenge her audience in order to provoke participation and feedback, she included the voice of Dinah. Suddenly, all three characters are playing tricks on each other and it is the audience which is left with the responsibility of deciding who the real trickster is.

As a contrast to the beginning of the folk tale, in which John is praying to be taken to heaven by God, the opening of Hurston's play exposes the audience to an ongoing quarrel between Ike and his wife Dinah. In Mules and Men, the story is told by Cliff Ulmer: "You know befo' surrender Ole Massa had a nigger name John and John always prayed every night befo' he went to bed and his prayer was for God to come git him and take him to Heaven right away. He didn't even want to take time to die. He wanted de Lawd to come git him just like he was - boot, sock and all" (73). In this introductory passage, the reader is acquainted with John's determination to die rather than to keep working for his master. While the story continues with the entrance of his master who disguises himself as the Lord by wearing a bed sheet in order to "find out if John meant dat thing" (73), Hurston's play begins with a dispute between Ike and his wife Dinah. The opening scene includes Dinah, obviously upset with her husband Ike, Ike, and their child. To Dinah's irritation, it seems that Ike is coming near to bring something to a desired state as can be seen in his preparation of a sweet potato. Though Ike is aware of her disgust, he goes on and kneels to pray. His praying is pretended, however, as can be further observed from his distraction by the potato. In comparison with 
the folk tale, the play portrays Ike as a plotter. Dinah's disapproving opinion of him and her further participation elevates her to a full character in the play.

Dinah's presence complicates the plot from a confrontation between two characters to one between three. To draw an even closer an analogy with the Signifying Monkey tale, the reflection of the story is further expressed in Dinah's words when she indirectly challenges her husband while talking to her child: "Honey you better go git some sleep befo' yo' pappy start his disturbance" (222). The word "disturbance" echoes the very beginning of the Signifying Monkey tale:
Deep down in the jungle so they say
There's a signifying monkey down the way
there hadn't been no disturbin' in the jungle for quite a bit, for up jumped the monkey in the tree one day and laughed
"I guess I'll start some shit." (Gates, Jr. 1988: 55)

In these verses, the term "disturbin"" connotates the act of provocation initiated by the Monkey. Due to the fact that Ike is also introduced as a plotter, Dinah's recognition of his plans classifies her as an equal participant of the confrontation between him and Ole Massa. As the conflict between the spouses intensifies, Dinah openly questions the intentions behind the prayers of her husband. The following accusation is completely missing from the original folk story: "DINAH: (Very annoyed) Yeah you bothers me! Every night heah, down on yo' rusty knees beggin' God to come git yuh and take ou to heben in his fiery chariot. You kno you don't want tuh die a bit more'n Ah do" (223). Dinah's open confrontation with her husband Ike gives her a position from which she can jeopardize Ike's endeavor. Though, as in the tale about the Signifying Monkey, there are three participants in the confrontation, the distribution of power is different. While the task of the Monkey is "to trick the Lion into tangling with the Elephant, who is the true King of the Jungle" (Gates, Jr. 1988: 56), Dinah is in an advantageous position in comparison with Ike, who had been traditionally established by the John stories as the main trickster, the Monkey.

The dispute between Dinah and Ike becomes an interesting part of the confrontation between Ike and Ole Massa, when she signifies on her husband using Ole Massa as a tool. While in the original tale John's wife Liza occupies a minor role in the main conflict of the story, Dinah continues to challenge her husband by signifying. Despite the possible objection that Hurston's act of giving voice to Dinah can be analyzed as Hurston's feminist interpretation of the original tale, it needs to be recalled that "singifyin(g) itself can be, and is, undertaken with equal facility and effect by women as well as men" (Gates, Jr. 1988: 54). Even during Hurston's research in the late 1920's women took part in these rhetorical combats as can be seen from the participation of Big Sweet in these oral combats in Mules and Men (97). In the following passages, I will compare the course of events in the original story and the play after Ole Massa suggested taking the wives in his fiery chariot as a result of John's and Ike's "absence": 
Liza says: "O, Lawd, John is right here underneath de bed."

"Come on John, and go to Heben wid me and its immortal glory."

John crept out from under de bed and went to de door and cracked it and when he seen all dat white standin' on de doorsteps he jumped back. He says: "O, Lawd, Ah can't go to Heben wid you in yo' fiery chariot in dese ole dirty britches; gimme time to put on my Sunday pants."

"All right, John, put on yo' Sunday pants."

John fooled around just as long as he could, changing them pants, but when he went back to de door, de big white glory was still standin' there. So he says agin: "O, Lawd, de Good Book says in Heben no filth is found and I got on dis dirty sweaty shirt. Ah can't go wid you in dis old nasty shirt. Gimme time to put on my Sunday shirt!" (74)

Here, despite Liza's telling on her husband, her presence is further in the story diminished and the main focus is on John trying to gain more time before he finally tricks his master. In the play, however, Dinah actively participates in the trick that Ole Massa tries to pull on Ike in order to get back to him. In other words, Dinah uses the language of her master but she uses it for her own purposes. Because it is suggested that Ike lured his master into trying to trick him in the opening of the play, instead of signifying on her master, Dinah signifies on her husband:

DINAH: God, Ike ain't gone nowhere, He's right here under dis bed.

OLE MASSA: Ike, O Ike. Why do you try to fool me? Come out from under that bed and go with me.

(Ike comes trembling forth, but turns upon Dinah and shakes his fist)

Dinah: You better not hit me. Ah'll holler and tell God on you.

(Ike desists)

OLE MASSA: Come on Ike, my chariot is tired of waiting.

IKE: (Drags to the door as slowly as possible and opens it. He visibly starts when he sees the white being outside.) O Lawd, You so white and clean, Ah know You don't want me to go to heben wid You in dese ole dirty clothes. Gime time to put on my Sunday shirt.

OLE MASSA: All right, Ike, go put on yo' Sunday shirt.

(Ike turns slowly and closes the door. He looks longingly at the window but sees again that it is too small. He starts to look under the bed as if he thinks his shirt could be under there.)

DINAH: (Jumps up and snatches the shirt off the wall and throws it to him angrily) You know no shirt ain't under dat bed. You jes' tryin to wear God out. IKE: (angrily) Who ast you to be so fast - findin' my shirt befo' I do? Ah got a mind to maul yo' knot for you. (Threatening)

DINAH: Aw, ole cuffy, you better gwan to heben while God want you. (224-225)

In this scene, it is obvious that the confrontation between Dinah and Ike overshadows the trick Ole Massa tries on Ike and vice versa. As the farce continues, 
Dinah strives to jeopardize her husband's efforts. While Ike tries to gain more time to add to the drama of his clever trick, Dinah deliberately acts as an obstacle to his plans. Moreover, she laughs at her husband by referring to her master as God. In this particular scene, Dinah performs the tasks of the trickster better than her husband.

Dinah's signifying on her husband requires answers from the audience of the play. The suggestion that Dinah is as equally skilled in signifying as her husband is suggested by the end of the play after Ike "outruns" his master. While the last lines of the original story are words of acclaim from Liza to her husband's wit: "Shet yo' mouf, talkin' foolishness!" Liza clashed at de chile. "You know de Lawd can't outrun yo' pappy specially when he's barefooted at dat" (75), Dinah's comment is the final, successfully executed blow to her husband in which she mocks the whole farce of him pretending his religious devotion: "Hush up dat foolishness and gwan back to sleep. You know God ain't got no time wid yo' pappy and him barefooted too" (226). A comparison of the closing of the folk tale with that of the play suggests that Hurston deliberately reshuffled words in the original ending in order to challenge her audience. The audience which was familiar with the formula of the folk stories about John had to decide who the real trickster was. While Ike still achieves his goal of tricking his master, which he seems to have plotted for some time in a similar way to the Monkey, Dinah, also like the Monkey, uses Ole Massa, the Elephant, to get back to Ike, the Lion.

In The Fiery Chariot, Hurston changed the original folk tale "Ole Massa and John Who Wanted to Go to Heaven" in a way that engages the audience which is familiar with such stories. The basic plot of the tale, which is the confrontation between John and Ole Massa, is extended to additional clash between Ike and his wife Dinah. The trinary force in the play resembles the Signifying Monkey tale in which The Monkey uses the Elephant to trick the Lion and humiliate him. In this way, Hurston suggests that both Ike and Dinah are the Monkey. The audience was expected to be challenged by choosing the main trickster in the play. Hurston's transformation of the original story into a play was based on intrinsic forms of African American expression. Hurston further encouraged the engagement of the audience precisely by complicating the formula of the original story.

\section{Spunk}

While my analysis of The Fiery Chariot was based on the comparison with a folk tale "Ole Massa and John Who Wanted to Go to Heaven," which had been collected by Hurston in Polk County in late 1920's, the play Spunk can also be discussed in terms of its difference from Hurston's short story "Spunk" (1925). Originally written as a tragedy, Hurston changed the play considerably by converting it into a comedy. More importantly, the plot is intertwined with numerous examples of folklore collected by Hurston in the Eatonville area and Polk County between 1928 and 1929. "One of the strengths of the play is the way in which 
Hurston weaves together song, story, and ethnography, retaining the fundamental dramatic structure of the story's plot while also incorporating cultural practices such as the toe party, croquet matches, lining songs, voodoo rites, and of course, the idiomatic expressions for which Hurston is best known" (Cole and Mitchell 2008: 227). The link between Hurston's research and examples of folklore being established, the aim of my discussion on Spunk in relation to Hurston's theatre is to show ways in which the audience was encouraged to participate in the performance. Given the amount of songs which appear in the play, I would like to argue that singing was intended to function as the bridge between the performance and the audience. In the following pages, I will analyze two excerpts from the play in which singing dominates and analyze its relevance for the African American audience in the South.

As has been stressed repeatedly, Hurston's interest in The Great Day, From Sun to Sun, and All De Live Long Day was to present her collection of African American folk songs in a way that would encourage the audience to participate and sing along. This idea is also reflected in Spunk in which some of the songs from these concerts are presented. At the opening of the play, the audience observes a group of working men line-singing. The centrality of song in the play is made prominent with the entrance of the main character Spunk, who makes impression on the working men engaged in line-singing by his skills as a guitar player and his good voice. However, it is the presentation of two widely known songs "This Old Hammer" and "Polk County" which is interesting because Hurston strategically used these songs at the beginning of the play to connect with her audience.

Both songs, "This Old Hammer' and "Polk County," were familiar to the African American community in Florida. "This Old Hammer" was a widely popular song, closely associated with John Henry, "a legendary freed slave who worked as a steel-driver on the Big Bend Tunnel of the C\&O Railroad, started in 1870 in Talcott, Wester Virginia" (Kaplan 2002: 489). The story about John Henry was based on the contest between him and "the steam-powered drill that would in time replace the labor of men's arms" (Jackson 2001: 60). However, "This Old Hammer" is a song about John Henry's death. The ballad was well-known to Hurston because she discusses it in "Folklore and Music" (1995: 880). The song remained in the African American folk culture since slavery and was, during the time of Hurston's research, favorite among railroad workers (Jackson 2001: 61). While "This Old Hammer" originated in West Virginia and spread across the South, "Polk County" was a famous song from Florida. This song echoed in Hurston's head when she was entering Polk County to do her research in 1928 which means she probably became familiar with the song when she was growing up in Eatonville. In Mules and Men she writes "Twelve miles below Kissimmee I passed under an arch that marked the Polk County line. I was in the famed Polk County. How often had I heard 'Polk County Blues"' (62). The popularity of the song is later revealed when she hears it from the working men themselves. The following moment, also from Mules and Men, is reflected in Spunk when Spunk 
plays the song on his guitar: "The guitars cried out 'Polk County,' 'Red River' and just instrumental hits with no name, that still are played by all good box pickers" (64).

The play opens with songs which were familiar to the audience in order to make them feel relaxed with the performance but as it develops, the creation of folk music and improvisation is displayed to the audience. The making of a song on the stage openly encourages the audience to participate. This scene depicts the community's discussion of the confrontation between the father of Lina's ex-husband, Bishop, who has a reputation of being a conjurer, and Spunk, Lina's current husband:

ORAL: Maybe things can be done, but I don't b'lieve old man Bishop can do none of it. I useter b'lieve, but since he done talked and prophesied all he was going to do to Spunk and ain't none of it come to pass, I don't b'lieve a thing. I don't b'lieve that lard is greasy. Let's sing off of it according to common meter. I'm going to line it out. Y'all sing! ([To the] tune of "Get on Board that Ship of Zion, It Has Landed Many a Thousand.")

Oh, Spunk Ain't scared of Bishop's conjure

Oh, Spunk Ain't scared of Bishop's conjure

Oh, Spunk Ain't scared of Bishop's conjure

He ain't scared, Lawd, he ain't scared.

(The others join in the spirit of fun. Full harmony.)

Oh, he done made sweet Lina love him

Oh, he done made sweet Lina love him

Oh, he done made sweet Lina love him

Wish "twas me, Lawd, wish 'twas me.

NUNKIE: Let me line out a verse, there. One done come to me:

He told me the boss's head a mess, Lawd

Told that boss's head a mess, lord (Oh sing it children)

Oh yes, he told his head a mess, Lawd

Ain't I glad, Lawd, ain't I glad.

MRS. WATSON: (Smiling) Ain't they crazy? (Laughing) If you all ain't the biggest fools I ever seen! (246-7)

This scene is a fascinating example of how the audience was asked to take part in the presented singing. Based on a hymn sung in the church "Get on Board that Ship of Zion, It Has Landed Many a Thousand," the song about Lina and Spunk was intimate to the audience as far as melody was concerned. However, the creation of the lyrics was familiar to the audience as well. According to Hurston in "Folklore and Music," "the oldest and most typical form of Negro blues is a line stating the mood of the singer repeated three times" (1995: 877) which is reflected throughout the creation of the song repeatedly. Moreover, Oral's command "Y'All Sing!" and Nunkie's "Oh sing it children" stimulate the participation of the observing audience in singing. Throughout the play, Hurston openly 
asked her audience to sing along. The performance of the play had the potential to display making of African American music authentically as sung by the folk.

Hurston's unique position among the New Negro intellectuals as both a writer of fiction and a trained anthropologist resulted in a specific interpretation of New Negro aesthetics in her works as well as in a diversion from Boasian ethnomethodology in her research. Hurston's plans for the "real Negro theatre" from early 1930 's reveal her awareness of the crucial role of interaction in the scientific method of participation observation that traditionally formulates conclusions about a community by eliminating the presence of an ethnographer. Hurston's attempts to uncover the dialogue between the African American folk community and herself is especially perceptible in her theatre. The performances From Sun to Sun (1932) and All De Live Long Day (1933), which took place in Eatonville area where her ethnographic research had taken place, were designed to encourage the participation of her audience and display folklore in making. From the ethnomethodological point of view, Hurston's approach is highly innovative because it is based on the same principle as a modern of version of participant observation which can be reformulated as "the observation of participation" (Tedlock 2005: 151). In the context of the theatre, the actively engaged audience was supposed to empower African American folk aesthetic. If read side by side with Hurston's conclusions from the field, The Fiery Chariot (1932) and Spunk (1935) can be interpreted in the way they elaborate on African American folklore. While The Fiery Chariot complicates the plot of a traditional folk tale in accordance with the practice of signifying, Spunk openly encourages the audience to sing along. With its inclusion of another trickster, The Fiery Chariot challenged its audience to discuss the real winner of the verbal combat. In Spunk, Hurston presented some of the most famous folk songs in the beginning of the play to make her audience feel relaxed and gradually proceeded to improvisation. Though the connection between the audience and the plays which Hurston envisaged would be hardly achieved today, this project should be recognized as a valuable attempt on the way to African American aesthetic freedom.

\section{References}

Castañeda, Quetzil E. (2006) "The Invisible Theatre of Ethnography: Performative Principles of Fieldwork." Anthropological Quarterly 79 (1): 75-104.

Clifford, James (1986) "Partial Truths." In: Clifford, James and George E. Marcus (eds.) Writing Culture: The Poetics and Politics of Ethnography. Berkeley: University of California Press, $1-26$.

Cole, Jean Lee, and Charles Mitchell (2008) "Introduction.” In: Cole, Jean Lee and Charles Mitchell (eds.) Zora Neale Hurston: Collected Plays. London: Rutgers University Press, xv-xxxiv.

Gates, Jr., Henry Louis (1988) The Signifying Monkey: A Theory of African-American Literary Criticism. Oxford: Oxford University Press.

Hemenway, Robert E. (1977) Zora Neale Hurston: A Literary Biography. London: University of Illinois. 
Hurston, Zora Neale (1995) "Folklore and Music." In: Wall, Cheryl A. (ed.) Memoirs and Other Writings. New York: Library of America, 875-894.

Hurston, Zora Neale (1943) "High John de Conquer." The American Mercury, 450-458.

Hurston, Zora Neale (1995) Mules and Men. In: Wall, Cheryl A. (ed.) Folklore, Memoirs and Other Writings. New York: Library of America, 5-175.

Hurston, Zora Neale (2008) The Fiery Chariot. In: Cole, Jean Lee and Charles Mitchell (eds.) Zora Neale Hurston: Collected Plays. London: Rutgers University Press, 222-226.

Hurston, Zora Neale (2008) Spunk. In: Cole, Jean Lee and Charles Mitchell (eds.) Collected Plays. London: Rutgers University Press, 229-268.

Jackson, Patricia Gale (2001) "If He Asks You Was I Running Tell Him I Was Flying, If He Asks You Was I Laughing You Tell Him I Was Crying: Reading John Henry as American History 1870." In: Goldner, Ellen J. and Safiya Henderson-Holmes (eds.) Racing \& (E)Racing Language: Living with the Color of Our Words. New York: Syracuse UP, 57-76.

Kaplan, Carla (2002) Zora Neale Hurston: A Life In Letters. New York: Doubleday.

Krasner, David (2002) A Beautiful Pageant: African American Theatre, Drama, and Performance in the Harlem Renaissance, 1910-1927. New York: Palgrave Macmillan.

Marcus, George E. and Michael M. J. Fischer (1999) Anthropology as Cultural Critique: An Experimental Moment in the Human Sciences. Chicago: University of Chicago Press.

Patterson, Tiffany Ruby (2005) Zora Neale Hurston and a History of Southern Life. Philadelphia: Temple UP.

Sanfield, Steve (1989) The Adventures of High John the Conqueror. August: Little Rock.

Schechner, Richard (1985) Between Theater and Anthropology. Philadelphia: University of Pennsylvania Press.

Schechner, Richard (2003) Performance Theory. New York: Routledge.

Smith, Ayana (2005) "Blues, Criticism, and the Signifying Trickster." Popular Music 24 (2): 179191.

Tedlock, Barbara (2005) "The Observation of Participation and the Emergence of Public Ethnography." In: Denzin, Norman K. and Yvonna S. Lincoln (eds.) The Sage Handbook of Qualitative Research. Thousand Oaks: Sage, 467-481.

Wintz, Cary D. and Paul Finkelman (2004) Encyclopedia of the Harlem Renaissance, Vol. 1. New York: Routledge.

Petra Slaví̌Ková is a doctoral student in the programme of Literatures in English at Masaryk University. Material for this article was collected for her master's thesis project while she was an exchange student at The University of Tennessee at Chattanooga. It is also an undirect continuation of another project in which she analyzed ethnographic aspects of Zora Neale Hurston novels Jonah's Gourd Vine and Their Eyes Were Watching God.

Address: Petra Slavíčková, Department of English and American Studies, Faculty of Arts, Masaryk University, Brno, Czech Republic. [email: 264221@mail.muni.cz] 
